\title{
QUANTITATIVE VARIATION WITHIN AND BETWEEN POPULATIONS OF THE WILD BARLEY, HORDEUM MURINUM
}

\author{
BARBARA E. GILES* AND K. J. R. EDWARDS \\ Department of Genetics, Cambridge University, Cambridge, England*
}

Received 19.iii.82

\section{SUMMARY}

\begin{abstract}
Variation in quantitative characters was studied in several wild populations and families of the weedy barley, Hordeum murinum. The hereditary, nonherediatary and interactive components of the variance were assessed for up to 13 metrical characters. Broad-sense heritabilities were calculated as were the relative contributions of populations, families and individuals to the overall variance. Correlation between characters was also considered. Significant genetic differences were observed between populations and between families within a population for developmental, morphological and reproductive characters. For most characters, the largest component of variance was due to population differences. Heritability was high for developmental characters and low for those associated with reproduction. The results have been discussed in light of experimental procedures used to assess the variation in wild populations for plant gene resource screening.
\end{abstract}

\section{INTRODUCTION}

This paper describes a study in which genetic variation for quantitative characters was assessed within and between populations of a wild barley. The growing interest in screening of populations of wild and weedy relatives of crop plants for genetic resource purposes led to this study.

It is common practice to analyse quantitative variation using biometrical techniques in the trials of cultivated varieties and breeding lines. Various individuals whose genetic relationships are known, are subjected to a range of environments or treatments. With appropriate experimental designs, the Genotype, Environment and Genotype-Environment Interaction variance components can be estimated and the performance of the varieties under different environments can be predicted (e.g., Yates and Cochran, 1938; Freeman and Dowker, 1973; Freeman, 1973; Ridgman, 1975; Moll and Stuber, $1974 ;$ etc.).

Assessment of the sources of quantitative variation in natural populations is more difficult (e.g. Hillel, Feldman and Simchen, 1973) due to problems associated with obtaining samples for which the genetic relationships between the individuals are known. Experiments must also be carried out under controlled conditions and there is a danger that inferences about the variation and its selection in the natural habitat may not be valid. However, measurement of quantitative variation using biometrical techniques in samples from wild populations grown in common environments can provide valuable information about the variation present in natural populations.

* Present address: Department of Crop Genetics and Breeding, Swedish University of Agricultural Sciences, S-26800 Svälof, Sweden. 
As an example, the quantitative variation was analysed in populations of the cleistogamous wild barley, Hordeum murinum. Several wild-collected populations were grown in controlled environments to determine the heritable, non-heritable and interactive components of the quantitative variation between populations, families or individuals and to calculate genetic correlation between characters.

\section{MATERIALS AND METHODS}

(i) Experimental design

Three experiments were carried out to investigate the variation in quantitative characters in $H$. murinum.

A randomised complete block design was used for the experiments. Equal numbers of plants from each family or population were allocated at random to each of four benches in a greenhouse. Each bench was treated as an experimental block; a random numbers table was used to allocate the plants within each block (table 1 ).

The three experiments consisted of the following:

Experiment I-16 individuals from each of 18 populations

Experiment II -8 individuals from each of 10 populations

Experiment III-8 seeds from each of the first heads of 47 individuals from 1 population

Material collected from the field as seed was used in Experiments I and II. Collection localities ranged from $50^{\circ} \mathrm{N}$ to $30^{\circ} \mathrm{N}$ latitude. In Experiment III each 8 seed set is a single full sib family obtained from a previous greenhouse experiment. Table 1 summarises the origins and experimental sample size of the material used in all three experiments.

The decimal code for Cereal Growth Stages was used as a standard by which to compare plants with different developmental times, morphology and reproductive behaviour (Zadoks et al., 1975; Tootman et al., 1979). Thirteen characters were analysed for this paper: Initial Seed Weight (SWt), Radicle Emergence (RAD), Coleoptile Emergence (COL), Leaf Through Coleoptile (LTC), First Leaf Unfolded (1st L), Second Leaf Unfolded (2nd $\mathrm{L})$, Tiller ( $\mathrm{T})$-number of days to attain a certain tiller number or numbers of tillers present on a certain day, Culm Length (CL), Flag Leaf Length (FLL), Flag Leaf Width (FLW), Spike Number (SpNo), Seed Number (SNo), and Fertile Seed Number (FSN).

\section{(ii) Statistical analysis}

The data from all three experiments were analysed by analyses of variance assuming a random effects model. None of the block $\times$ population/family mean squares were significantly different from the sample variances in Experiments I, II or III. Thus both sources of variance were pooled to give the appropriate estimate of the error variance.

A crude approximation of the relative contributions of population, family and individual to the overall variance was estimated from Experiments II and III in the following way:

$$
\text { Let } \operatorname{Var}(Y)=\hat{\sigma}_{p}^{2}+\hat{\sigma}_{f}^{2}+\hat{\sigma}_{e}^{2}
$$


TABLE 1

Hordeum murinum populations and sample sizes used in statistical analysis of Experiments $I$, II and III

\begin{tabular}{|c|c|c|c|}
\hline Population & Latitude & Block & $\begin{array}{c}\text { Population } \\
\text { Family }\end{array}$ \\
\hline \multicolumn{4}{|l|}{ Experiment I } \\
\hline Hartlepool, Cleveland & $54^{\circ} 40^{\prime} \mathrm{N} / 1^{\circ} 15^{\prime} \mathrm{W}$ & 4 & 16 \\
\hline York, Yorkshire & $53^{\circ} 58^{\prime} \mathrm{N} / 1^{\circ} 5^{\prime} \mathrm{W}$ & 4 & 16 \\
\hline Shrewsbury, Shropshire & $52^{\circ} 12^{\prime} \mathrm{N} / 2^{\circ} 15^{\prime} \mathrm{W}$ & 4 & 16 \\
\hline Lowestoft, Suffolk & $52^{\circ} 29^{\prime} \mathrm{N} / 1^{\circ} 45 / \mathrm{E}$ & 4 & 16 \\
\hline Worcester, Worcestershire & $52^{\circ} 12^{\prime} \mathrm{N} / 2^{\circ} 15^{\prime} \mathrm{W}$ & 4 & 16 \\
\hline Grantchester, Cambridgeshire & $52^{\circ} 12^{\prime} \mathrm{N} / 0^{\circ} 8^{\prime} \mathrm{W}$ & 4 & 16 \\
\hline Cambridge, Cambridgeshire & $52^{\circ} 12^{\prime} \mathrm{N} / 0^{\circ} 8^{\prime} \mathrm{W}$ & 4 & 16 \\
\hline Oxford, Oxfordshire & $51^{\circ} 48^{\prime} \mathrm{N} / 1^{\circ} 15^{\prime} \mathrm{W}$ & 4 & 16 \\
\hline Porteynon, S. Glamorgan & $51^{\circ} 34^{\prime} \mathrm{N} / 3^{\circ} 15^{\prime} \mathrm{W}$ & 4 & 16 \\
\hline Barry, S. Glamorgan & $51^{\circ} 25^{\prime} \mathrm{N} / 3^{\circ} 25^{\prime} \mathrm{W}$ & 4 & 16 \\
\hline Guernsey, Channel Is. & $49^{\circ} 31^{\prime} \mathrm{N} / 3^{\circ} 25^{\prime} \mathrm{W}$ & 4 & 16 \\
\hline Castel des Biches, France & $49^{\circ} 15^{\prime} \mathrm{N} / 3^{\circ} 10^{\prime} \mathrm{W}$ & 4 & 16 \\
\hline Pisa, Italy & $43^{\circ} 45^{\prime} \mathrm{N} / 10^{\circ} 20^{\prime} \mathrm{E}$ & 4 & 16 \\
\hline Aix, France & $43^{\circ} 30^{\prime} \mathrm{N} / 5^{\circ} 30^{\prime} \mathrm{E}$ & 4 & 16 \\
\hline Paradis d'Ete, Italy & $43^{\circ} 8^{\prime} \mathrm{N} / 12^{\circ} 25^{\prime} \mathrm{E}$ & 4 & 16 \\
\hline Golan Heights, Israel & $33^{\circ} 5^{\prime} \mathrm{N} / 35^{\circ} 35^{\prime} \mathrm{E}$ & 4 & 16 \\
\hline Acco Plain, Israel & $32^{\circ} 50^{\prime} \mathrm{N} / 35^{\circ} 10^{\prime} \mathrm{E}$ & 4 & 16 \\
\hline Western Negev, Israel & $30^{\circ} 50^{\prime} \mathrm{N} / 34^{\circ} 45^{\prime} \mathrm{E}$ & 4 & 16 \\
\hline \multicolumn{4}{|l|}{ Experiment II } \\
\hline Pisa, Italy & $43^{\circ} 45^{\prime} \mathrm{N} / 10^{\circ} 20^{\prime} \mathrm{E}$ & 2 & 8 \\
\hline Aix, France & $43^{\circ} 30^{\prime} \mathrm{N} / 5^{\circ} 30^{\prime} \mathrm{E}$ & 2 & 8 \\
\hline S. Peloponessos, Greece & $36^{\circ} 30^{\prime} \mathrm{N} / 22^{\circ} 30^{\prime} \mathrm{E}$ & 2 & 8 \\
\hline W. Rhodes, Greece & $36^{\circ} 15^{\prime} \mathrm{N} / 27^{\circ} 50^{\prime} \mathrm{E}$ & 2 & 8 \\
\hline Crete, Greece & $35^{\circ} 20^{\prime} \mathrm{N} / 23^{\circ} 30^{\prime} \mathrm{E}$ & 2 & 8 \\
\hline Golan Heights, Israel & $35^{\circ} 5^{\prime} \mathrm{N} / 35^{\circ} 35^{\prime} \mathrm{E}$ & 2 & 8 \\
\hline Acco Plain, Israel & $32^{\circ} 50^{\prime} \mathrm{N} / 35^{\circ} 10^{\prime} \mathrm{E}$ & 2 & 8 \\
\hline Western Negev, Israel & $30^{\circ} 50^{\prime} \mathrm{N} / 34^{\circ} 45^{\prime} \mathrm{E}$ & 2 & 8 \\
\hline Cairo, Egypt & $30^{\circ} 3^{\prime} \mathrm{N} / 31^{\circ} 15^{\prime} \mathrm{E}$ & 2 & 8 \\
\hline Canterbury, N.Z. & $44^{\circ} 45^{\prime} \mathrm{S} / 171^{\circ} 35^{\prime} \mathrm{E}$ & 2 & 8 \\
\hline $\begin{array}{l}\text { Experiment III } \\
47 \text { Families from Pisa-grown in a previous } \\
\text { experiment }\end{array}$ & $43^{\circ} 45^{\prime} \mathrm{N} / 10^{\circ} 20^{\prime} \mathrm{E}$ & 2 & 8 \\
\hline
\end{tabular}

where $\hat{\sigma}_{p}^{2}=$ variance component due to populations from Experiment II, $\hat{\sigma}_{f}^{2}=$ variance component due to families from Experiment III, $\hat{\sigma}_{e}^{2}=$ variance component from the pooled error from Experiment III.

The percentage of total variation attributable to population, family or sampling error was calculated

$$
R_{p}^{2}=\frac{\hat{\sigma}_{p}^{2}}{\operatorname{Var}(Y)} \cdot 100, \quad R_{f}^{2}=\frac{\hat{\sigma}_{f}^{2}}{\operatorname{Var}(Y)} \cdot 100, \quad R_{e}^{2}=\frac{\hat{\sigma}_{e}^{2}}{\operatorname{Var}(Y)} \cdot 100
$$

$R_{p}^{2}, R_{f}^{2}$ and $R_{e}^{2}$ values were calculated for the nine characters which had been measured identically in Experiments II and III.

A broad-sense heritability (Falconer, 1960) was calculated for each character based on the variance components estimated from the analysis of variance (Experiment III). 
To stabilise the variances, a logarithmic transformation was performed on the data for the characters SWt, RAD, COL, LTC, 1st L and 2nd L.

\section{RESULTS}

The results of the analyses of variance for 13 characters measured in Experiments I and II appear in table 2. No block effects were observed in Experiments I or II but significant block differences were obtained for the characters RAD, COL, LTC, 1st L, 2nd L, T2, TND134 and CL in Experiment III. Significant genetic differences were observed between populations for all characters measured in Experiments I and II and similarly between families in Experiment III for all but flag leaf and spike characters.

TABLE 2

Mean squares from the Analysis of Variance, Experiments I, II, III

\begin{tabular}{|c|c|c|c|c|c|c|c|c|}
\hline & & & df & SWt & RAD & COL & LTC & 1 st L \\
\hline \multicolumn{9}{|l|}{ Experiment 1} \\
\hline block & & & 3 & 0.0595 & 0.0400 & 0.0034 & & 0.0033 \\
\hline between populations & & & 17 & 0.3375 & $0.1694 t$ & $0.1361 \dagger$ & & $0.0953 \div$ \\
\hline pooled error & & & 267 & 0.0036 & 0.0257 & 0.0254 & & 0.0176 \\
\hline \multicolumn{9}{|l|}{ Experiment II } \\
\hline block & & & 3 & 0.0367 & 0.0103 & 0.0109 & & 0.0032 \\
\hline between populastions & & & 9 & 0.2305 & $0.0586^{\dagger}$ & $0.0153^{*}$ & & 0.0037 \\
\hline pooled error & & & 67 & 0.0269 & 0.0167 & 0.0072 & & 0.0033 \\
\hline \multicolumn{9}{|l|}{ Experiment III } \\
\hline block & & & 3 & 0.0230 & $0.1189 t$ & $0.0797+$ & $0.0521+$ & $0.0364 \div$ \\
\hline between families & & & 46 & $0.0626+$ & 0.2385 & $0.1085+$ & $0.0697+$ & 0.0555 \\
\hline pooled error & & & 326 & 0.0209 & 0.0286 & 0.0133 & 0.0095 & 0.0084 \\
\hline \multicolumn{9}{|l|}{$\begin{array}{l}* P<0.05 \\
+P<0.01\end{array}$} \\
\hline & $T-B$ & $\mathrm{~T}-\mathrm{C}$ & $\mathrm{CL}$ & FLL & FLW & SpNo & SNo & FSN \\
\hline \multicolumn{9}{|l|}{ Experiment 1} \\
\hline block & $35 \cdot 73$ & - & - & - & - & - & - & - \\
\hline between populations & $160 \cdot 32 \div$ & - & - & - & - & - & - & - \\
\hline pooled error & 13.93 & - & 一 & - & - & - & - & - \\
\hline \multicolumn{9}{|l|}{ Experiment 11} \\
\hline block & 42.58 & - & 6108 & $88 \cdot 10$ & 1.683 & $15 \cdot 11$ & 5154 & 4228 \\
\hline between populations & $370.03+$ & - & $97229+$ & $673.84 \%$ & $4 \cdot 283^{\dagger}$ & $122 \cdot 53^{\dagger}$ & $55859 \div$ & 35709 \\
\hline pooled error & 44.48 & - & 4901 & $85 \cdot 57$ & 0.6261 & 8.42 & 2992 & 2243 \\
\hline \multicolumn{9}{|l|}{ Experiment III } \\
\hline block & $21 \cdot 386$ & 85.47 & $47972+$ & $717 \cdot 1$ & 3.513 & 9.733 & - & $\rightarrow$ \\
\hline between families & $8 \cdot 344 t$ & $41.62+$ & $15740^{\circ}$ & $605 \cdot 1^{*}$ & 2.798 & 6.938 & - & - \\
\hline pooled error & 3.493 & $14 \cdot 35$ & 8155 & 376.5 & $2 \cdot 228$ & 4.913 & - & - \\
\hline
\end{tabular}

The relative contributions by individuals, families and populations to the total variance were compared (table 3 ). In seven of the nine characters examined, the between population component of variance was generally the largest (40-90 per cent) while the individual component of variance accounted for only 4-6 per cent of the total. It is noteworthy that in the characters SWt, CL and SpNo more than 80 per cent of the total variance was contributed by the population component. In the flag leaf characters, however, the individual component of variance is large ( 23 per cent) and 
the family and population components are similar to each other $(\simeq 40$ per cent).

The heritability of each character calculated from the analysis of variance for full sib families is shown in table 3. In general, heritabilities for the characters associated with reproduction are lower than those associated with early growth and development; e.g., the $h^{2}$ calculated for SpNo or CL are lower than those for RAD or COL. This pattern is consistent with other studies in which low heritabilities are often found for characters closely associated with reproductive fitness (Falconer, 1960; Allard, 1960; Lewontin, 1974). In this study, three characters associated with reproduction (SpNo, CL, SWt) which have low $h^{2}$, also have $R_{p}^{2}$ values in excess of 80 per cent. Very little of the total variance is contributed by the between-family component of variance. Flag leaf characters also have low $h^{2}$ but the individual and family components of variance $\left(\boldsymbol{R}_{f}^{2}, \boldsymbol{R}_{e}^{2}\right)$ for these characters are sizeable. The sequence of developmental characters (RAD through 2 nd L), have high $h^{2}$ and relatively large $R_{f}^{2}$.

\section{TABLE 3}

Percentage of total variance contributed by populations $\left(\boldsymbol{R}_{p}^{2}\right)$, families $\left(\boldsymbol{R}_{f}^{2}\right)$ and individual $\left(R_{e}^{2}\right)$ and broad-sense heritability estimates with confidence intervals $\left(t_{0.025}\right)$ calculated from Experiment III by full-sib method (Falconer, 1960)

\begin{tabular}{|c|c|c|c|c|}
\hline Character & $\mathbf{R}_{\mathrm{p}}^{2}$ & $\mathbf{R}_{\mathrm{f}}^{2}$ & $\mathbf{R}_{e}^{2}$ & $\begin{array}{l}\text { Broad-dense } \\
\text { heritability }\end{array}$ \\
\hline Seed weight & $80 \cdot 17$ & 14.87 & 4.96 & $0.22 \pm 0.19$ \\
\hline Radicle emergence & $38 \cdot 81$ & 54.65 & 6.54 & $0.51 \pm 0.29$ \\
\hline Coleoptile emergence & $52 \cdot 78$ & 42.05 & $5 \cdot 17$ & $0.48 \pm 0.28$ \\
\hline Leaf through coleoptile & - & - & - & $0.45 \pm 0.27$ \\
\hline First leaf & 59.96 & 34.85 & $5 \cdot 26$ & $0.43 \pm 0.27$ \\
\hline Second leaf & 67.96 & $28 \cdot 37$ & 3.67 & $0.47 \pm 0.28$ \\
\hline Tiller 1 & - & - & - & $0 \cdot 22 \pm 0.19$ \\
\hline Tiller 2 & - & - & - & $0.13 \pm 0.14$ \\
\hline Tiller number day 134 & - & - & - & $0.20 \pm 0.13$ \\
\hline Culm length & $80 \cdot 27$ & 13.00 & 6.73 & $0.12 \pm 0.14$ \\
\hline Flag leaf length & $40 \cdot 71$ & 36.55 & $22 \cdot 74$ & $0.09 \pm 0.12$ \\
\hline Flag leaf width & $46 \cdot 01$ & 30.06 & 23.93 & $0.14 \pm 0.14$ \\
\hline Spike number & $91 \cdot 18$ & $5 \cdot 16$ & 3.66 & $0.07 \pm 0.07$ \\
\hline
\end{tabular}

\section{(ii) Correlation between characters}

As a large number of biologically related characters have been chosen for study, the possibility of character correlation is high. The genotypic correlation matrix for Experiment III appears in table 4. Particular groups of characters were correlated. The groups were:

(a) Sequential developmental characters: RAD, COL, LTC, 1st L, 2nd L; certain tiller characters.

(b) Different measurements of the same morphological characters: FLL, FLW.

(c) Different measurements of reproductively related characters: SpNo, SNo, FSN. 
TABLE 4

Genotypic correlation matrix for characters measured in Experiment III $(n=376)$

\begin{tabular}{lrrrrrrr}
\hline 1. SWt & 1.00 & - & - & - & - & - & - \\
2. RAD & -0.39 & 1.00 & - & - & - & - & - \\
3. COL & -0.31 & 0.95 & 1.00 & - & - & - & - \\
4. LTC & -0.29 & 0.95 & 0.98 & 1.00 & - & - & - \\
5. 1st L & -0.24 & 0.92 & 0.97 & 0.96 & 1.00 & - & - \\
6. 2nd L & -0.48 & 0.92 & 0.93 & 0.94 & 0.91 & 1.00 & - \\
7. T-1 & 0.48 & -0.74 & -0.75 & -0.77 & -0.75 & -0.80 & 1.00 \\
8. T-2 & 0.41 & -0.65 & -0.67 & -0.68 & -0.73 & -0.73 & 0.72 \\
9. TND134 & 0.15 & 0.19 & 0.15 & 0.19 & 0.23 & 0.18 & -0.18 \\
10. CL & -0.19 & 0.00 & 0.04 & 0.05 & -0.05 & 0.02 & -0.07 \\
11. FLL & 0.09 & 0.17 & 0.12 & 0.10 & 0.14 & 0.10 & -0.04 \\
12. FLW & -0.19 & 0.21 & 0.22 & 0.23 & 0.22 & 0.31 & -0.24 \\
13. SpNo & 0.02 & 0.18 & 0.13 & 0.13 & 0.14 & 0.11 & -0.20 \\
& SWt & RAD & COL & LTC & 1 st L & 2 nd L & T-1 \\
\hline
\end{tabular}

\begin{tabular}{|c|c|c|c|c|c|c|}
\hline 1. $S W t$ & - & - & - & - & - & - \\
\hline 2. RAD & - & - & - & - & - & - \\
\hline 3. COL & - & - & - & - & - & - \\
\hline 4. LTC & - & - & - & - & - & - \\
\hline 5. 1st L & - & - & - & - & - & - \\
\hline 6. 2nd L & - & - & - & - & - & - \\
\hline 7. $T-1$ & - & - & - & - & - & - \\
\hline 8. T-2 & 1.00 & - & - & - & - & - \\
\hline 9. TND134 & -0.26 & 1.00 & - & - & - & - \\
\hline 10. CL & -0.04 & -0.46 & 1.00 & - & - & - \\
\hline 11. FLL & $-0 \cdot 16$ & -0.01 & 0.12 & 1.00 & - & - \\
\hline 12. FLW & -0.36 & $-0 \cdot 13$ & 0.26 & 0.54 & 1.00 & - \\
\hline \multirow[t]{2}{*}{ 13. SpNo } & -0.08 & 0.64 & -0.35 & $0 \cdot 19$ & 0.14 & 1.00 \\
\hline & $\mathrm{T}-2$ & TND134 & $\mathrm{CL}$ & FLL & FLW & SpNo \\
\hline
\end{tabular}

The correlation coefficients for characters within the different character groups described above are highly significant and generally homogeneous (e.g., RAD, COL, LTC, 1st L, 2nd L). Correlation coefficients for characters which are not part of the same character group are either nonsignificant or opposite in sign (e.g., Tiller character characters vs. RAD, COL, LTC, 1st $\mathrm{L}, 2$ nd L). A more detailed treatment of the character correlations is not in keeping with the rest of this paper.

\section{Discussion}

The experimental design used in these analyses was not very efticient since the family variance was estimated from one population only. Had a nested design of several families within each population being tested, more precise estimation of the variance components would have been possible. Nevertheless, the present analyses clearly indicate that:

(a) Ample genetic variation exists in populations and families of wild Hordeum murinum for a number of characters.

(b) The major contributing source of genetic variance differed with character. 
For reproductive characters, most of the variance was found between populations. A large percentage of the total variance was contributed by families within populations in the developmental characters. Generally, the population component contributed the largest portion of the total variance.

(c) There was evidence for genetic correlation between characters, possibly suggesting that groups of characters might respond or may have responded to selection as a single unit.

It would be inappropriate to draw inferences from the results about the role of the phenotypic variation and selective forces in the habitats from which the plants were collected. However, the information gained from these types of experiments can be useful because such experiments create a common ground in which the relative genotypically or environmentally induced responses of plants obtained from diverse sources can be judged. In the experiments, the environments provided by the four blocks are micro-environments and are also not under the control of the investigator. Valuable information on the effects of environment on the range of character expression could be obtained by increasing the number of test environments. However, this study can make a contribution to the evaluation of gene resource material.

There is a growing realisation that little genetic variation upon which artificial selection can be practised remains in many cultivated plants. To counteract this situation, wild and weedy relatives and primitive varieties are collected and preserved to capture and make available to breeders as much genetic variation as possible. The material, however, must be evaluated for two reasons: (a) to determine the amount of genetic variation in agronomically useful characters in material already collected (e.g. IBPGR, 1978); (b) to establish the distribution pattern of the genetic variation within and between populations so that statistical recommendations for optimum sample sizes and number of collection sites can be made for maximal capture of genetic variation in future collections. Evaluation of resource material is an applied version of a problem well known to population geneticists; that is, how much genetic variation exists in natural populations and how is it distributed.

Of (a) and (b), (b) is the most difficult problem to address because the collection strategies recommended vary with the type of characters used to study the distribution of genetic variation in populations (Allard, 1970; Bennett, 1970; Qualset, 1975; Marshall and Brown, 1975, 1981; Tolbert et al., 1980; Witcombe and Gilani, 1979; Bogyo et al., 1980; Brown and Munday, 1982). The results of this paper suggest that collection strategies will vary with the character of interest. If the aim is to capture variation for reproductive characters (e.g., yield, flowering time) then clearly the best strategy is to collect material from different populations over a wide eco-geographic range because the genetic variance observed within a population for these characters is low. Alternatively, if the interest lies in characters such as germination time or rate of seedling development, then ample variation may be found within a population. Overall, the between population component of variance was large for all characters used in this study including the seedling developmental characters (tables 2 and 3 ). Thus if a general recommendation can be made for capture of maximum 
genetic variation from populations of Hordeum murinum, the best strategy would maximise the number of collection sites in as many distinct egogeographic areas as possible.

Ultimately, the answer to (b) requires a reliable guide to genetic structure of populations. We do not yet have the ability to reconstruct the overall pattern of genetic variation in a population from the patterns indicated by a small sample of characters. Thus to assess variation in arbitrarily chosen or easy-to-assess sets of characters, with the hope that the variation uncovered is typical of the genome as a whole, is little more than pious hope (see Giles, in press). The first step in examining a wild population for genetic variation is to have a clear idea of what characters should be examined; this being determined by the use to which the variation will be put. It is only through the use of suitable experimental designs that a reasonably true estimate of genetic variation in wild-collected material can be made. The methodology of biometrical genetics provides an excellent framework for further studies of the genetic variation in natural populations. A great deal of valuable information could be obtained by exploiting the potential of this methodology.

Acknowledgments.-Special thanks to Dr J. A. Barrett and Dr C. S. Lin for invaluable comments and discussion. Support (to BEG) was provided by the Perry Foundation, Boreham, Chelmsford, Essex, Ref. No. 335659, England.

\section{REFERENCES}

ALLARD. R. W. 1960 Principles of Plant Breeding. John Wiley and Sons, Inc., New York, London.

ALlARD, R. W. 1970. Population structure and sampling methods. In Frankel, O. H. and Bennett E. (eds.) Genetic Resources in Plants, IBP Handbook No. 11. Blackwell Scientific Publications, Oxford and Edinburgh.

BENNETT, E. 1970. Tactics in plant exploration. In Frankel, O. H. and Bennett, E. (eds.), Genetic Resources in Plants-their Exploration and Conservation. IBP Handbook, No. 11, Blackwell, Oxford and Edinburgh, pp. 157-179.

BOGYO, T. P., PORCEDDU, E. AND PERRINE, P. 1980. Analysis of sampling strategies for collecting genetic material. Econ. Bot., 34, 160-174.

BROWN, A. H. D. AND MUNDAY, J. 1982. Population-genetic structure and optimum sampling of land races of barley from Iran. Genetica, 58, 85-96.

FALCONER, D. S. 1960. Introduction to Quantitative Genetics. Oliver and Boyd. Edinburgh and London.

FREEMAN, G. H. 1973. Statistical methods for the analysis of genotype-environment interactions. Heredity, 31, 339-354.

FREEMAN, G. H. AND DOWKER, B. D. 1973. The analysis of variation between and within genotypes and environments. Heredity, 30, 97-110.

GILES, B. E. 1983. A comparison between quantitative and biochemical variation in the wild barley Hordeum murinum. Evolution (in press).

HILlEL, J., FELDMAN, M. W. AND SIMCHEN, G. 1973. Mating systems and population structure in two closely related species of the wheat group. I. Variation between and within populations. Heredity, 30, 141-167.

IBPGR. 1978. Descriptors of wheat and Aegilops. IBPGR Secretariat, Rome,

LEWONTIN, R. C. 1974. The Genetics of Evolutionary Change. Columbia University Press. New York.

MARSHALL, D. R. AND BROWN, A. H. D. 1975. Optimum sampling strategies in genetic conservation. In Frankel, O. H. and Hawkes, J. G. eds.) Crop Genetic Resources for Today and Tomorrow. IBP Vol. 2. Cambridge University Press. GB 1975. 
MARSHALL, D. R. AND BROWN, A. H. D. 1981. Wheat genetic resources. In Evans, L. T. and Peacock, W. J. (eds.) Wheat Science-today and tomorrow, Cambridge University Press, pp. 21-40.

MOLL, R. H. AND STUBER, C. W. 1974. Quantitative Genetics--empirical results relevant to plant breeding. Adv. in Agron., 26, 277-313.

QUALSET, C. O. 1975. Sampling germplasm in a centre of diversity: and example of disease resistance in Ethiopian barley. In Frankel, O. H. and Hawkes, J. G. (eds.) Crop Genetic Resources for Today and Tomorrow. Cambridge University Press. Cambridge, pp. 81-96.

RIDGMAN, w. J. 1975. Experimentation in Biology. An Introduction to Design and Analysis. Blackie, Glasgow and London.

TOLBERT, D. M., QUALSET, C. O., JAIN, S. K. AND CRADDOCK, J, C. 1980. A diversity analysis of a world collection of barley. Crop. Sci., 19, 789-794.

TOTTMAN, D. R., MAKEPEACE, R. J. AND BROAD, H. 1979. An explanation of the decimal code for the growth stages of cereals, with illustrations. Ann. Appl. Biol., 93, 221-234.

WITCOMBE, J. R. AND GILANI, M. M. 1979. Variation in cereals from the Himalayas and the optimum strategy for sampling plant germplasm. J. Applied Ecol., 16, 633-640.

YATES, F. AND COCHRAN, W. G. 1938. The analysis of group experiments. J. Agricultural Sci., 28, 556-580.

ZADOKS, J. C., CHANG, T. T. AND KONZAK, C. F. 1974. A decimal code for the growth stages of cereals. Eucarpia Bull. No. 7 (European Association for Research on Plant Breeding, Wageningen, Netherlands). 